\title{
Subjectivity in Contemporary Visualization of Reality: Re-visiting Ottoman miniatures
}

\author{
Murat Germen \\ Sabanci University \\ FASS, Orhanli, Tuzla, 34956, Istanbul, Turkey \\ muratgermen@sabanciuniv.edu
}

\begin{abstract}
Though Ottoman miniatures are 2D representations, they carry the potential of conveying an individual's perception in a more detailed manner as compared to 3D perspective renderings. In a typical 2-vanishing-point perspective; objects / subjects drawn in the foreground hide the ones that are located at their back: This phenomenon is called occlusion. In Ottoman miniatures there is no occlusion, all object / subject illustrations are wholistic, there is no partial description of figures. Consequently, you end up with a life form that is the synthesis of individual forms, a sui generis state... This unique visual narrative can be extended to cubist works where multifaceted descriptions are observed.
\end{abstract}

\begin{abstract}
Another advantage of Ottoman miniatures is that hierarchies of image and image maker are quite clear. Miniatures make use of distance, void, shape, scale relationships and their layout to give a sense of depth in space. Though objectivity is very much valued in visual representation, ideal objectivity is not possible since representations are created by subjects and subjects belong to cultures that have different criteria in forming / perceiving portrayals. Moreover, tools that are used for visual representations usually prove to be narrower than the scope of human perception.

Departing from the point of view explained above, Muta-morphosis is a photography project that is created as an almost surreal visualization stemming from the real. The lack of a single perspectival structure due to multiplicity of perspectives after compressed panoramic imaging, can be linked to Ottoman miniatures, which in turn, connects the global contemporary representation to its local traditional counterpart.
\end{abstract}

Ottoman miniature painting, contemporary photography, child drawings, visualization, representation, reality, documentary, subjectivity, objectivity, visual narration.

\section{INTRODUCTION}

I have always had a deep interest in visual representations with unique pictorial language, distinctive methods of conveying content and exceptional local / individual identity. Manga drawings, matte paintings, Lebbeus Woods' drawings of architectural fantasies, monochromatic physical architectural models where a single material is used for construction, Lego constructions / designs, Piranesi etchings, wireframe renders and miniature paintings are among some of these much appreciated representations. This paper will take Ottoman miniatures in particular, and focus on the subjective dimension in the making of this exclusive illustration technique and finally compare it to a digital photography based contemporary artwork series entitled 'Muta-morphosis.'

The word miniature, derived from the Latin minium, red lead, is a picture in an ancient or medieval illuminated manuscript; the simple decoration of the early codices having been miniated or delineated with that pigment. The generally small scale of the medieval pictures has led to an etymological confusion of the term with minuteness and to its application to small paintings especially portrait miniatures, which, however, grew from the same tradition and, at least initially, used similar techniques. 
Apart from the Western and Byzantine traditions, there is a group of Asian traditions which is generally more illustrative in nature. From origins in manuscript book decoration, this developed into single-sheet small paintings to be kept in albums, which are also called miniatures, as the Western equivalents in watercolour and other media are not. These include Persian miniatures, and their Mughal, Ottoman and other Indian offshoots. (Wikipedia 2012b)

\section{HISTORICAL BACKGROUND ON OTTOMAN MINIATURES AS DOCUMENTATION OF REALITY}

Ottoman miniature as a factual visualization tool is at the same time a significant art form of the Ottoman Empire, though not solely intended as artistic expression.

Earliest Ottoman painters used Persian artistic features in their space conception and renditions of landscape and figures. This was reinforced by the known fact that during the Turkish campaigns of the early XVIth century, Persian artists were captured and subsequently attached to the imperial studios. Yet, to regard Turkish painting solely from the point of view of Persian miniatures is doing it as much injustice as if one were to regard Japanese painting as a subspecies of the art of China. Persian painting is just one of the sources of Turkish art. Perhaps the most startling difference between Persian and Turkish painting is the subject matter. In Iran, painters illustrated works which dealt with the duels or other exploits of heroes of the distant national past, or with romantic stories, often having unrequited love as their theme. In contrast to such idealized heroic or amatory experiences of individual legendary figures, Turkish paintings treated the recent history of the state. When it comes to the inner qualities of Turkish painting, perhaps the outstanding ones are those of vitality, power and directness of presentation. Their aim was to create the impression of physical strength and to have it experienced as something immediate and real. (Ettinghausen, et al 1961)

A similar observation that strengthens the thesis that Ottoman miniature differs from its Persian counterpart, in the sense of being relatively more objective, goes as follows:

Within the scope of Ottoman miniature painting a cycle of illustrations increases in importance the more obviously it distances itself from the Persian 'model' by its choice of subjects and by its formal solutions. (Rührdanz 1994)

This objectivity is further emphasized by Nurhan Atasoy, one of Turkey's leading and most respected art historians:

One of the most important characteristics of Turkish miniatures is their documentary value. Miniatures can tell us more about daily life than can be learned from the written sources alone. (Atasoy 1976)

This documentary approach obviously takes Ottoman miniature to an esteemed position since it carries the potential of being reliable as historical documentation. These fairly faithful visual depictions, avoiding overstatement and whimsicality, can be utilized as resources to make assessments on Ottoman architecture, society, people, urban life, costumes, traditions and so on. Following the text cited from academics and historians above, it is possible to say that the Ottoman miniature making process was not originally envisioned as an art form, but rather as objective (as possible) documentation having a subjective language. Another dimension that can be taken as an attitude towards such neutrality is the fact that, "the miniatures were not signed; this is partly because of the world view of the tradition that rejected individualism", (Wikipedia 2012a) which refers mostly to subjectivity, while anonymity as a result of the lack of personal signature suggests objectivity.

Photography, especially early photography, concentrated on witnessing life, providing people with historical / official / casual / collective / individual evidence, testifying for existence. This mode of photographical practice is still around, and will persistently continue; as there will always be need for documentary photos to be used in newspapers, TV channels on news / documentary, books, encyclopaedias and so on. Photography's documentary dimension remains essential and will stay to be so. Co-existing with classical documentary photography, contemporary art photography does not freeze existing moments as its counterpart did at the beginning, but rather creates moments that did not exist at all. Ottoman miniatures' and photography's objective documentary and subjective fictional natures are comparable and the next section will expand on this connection. 

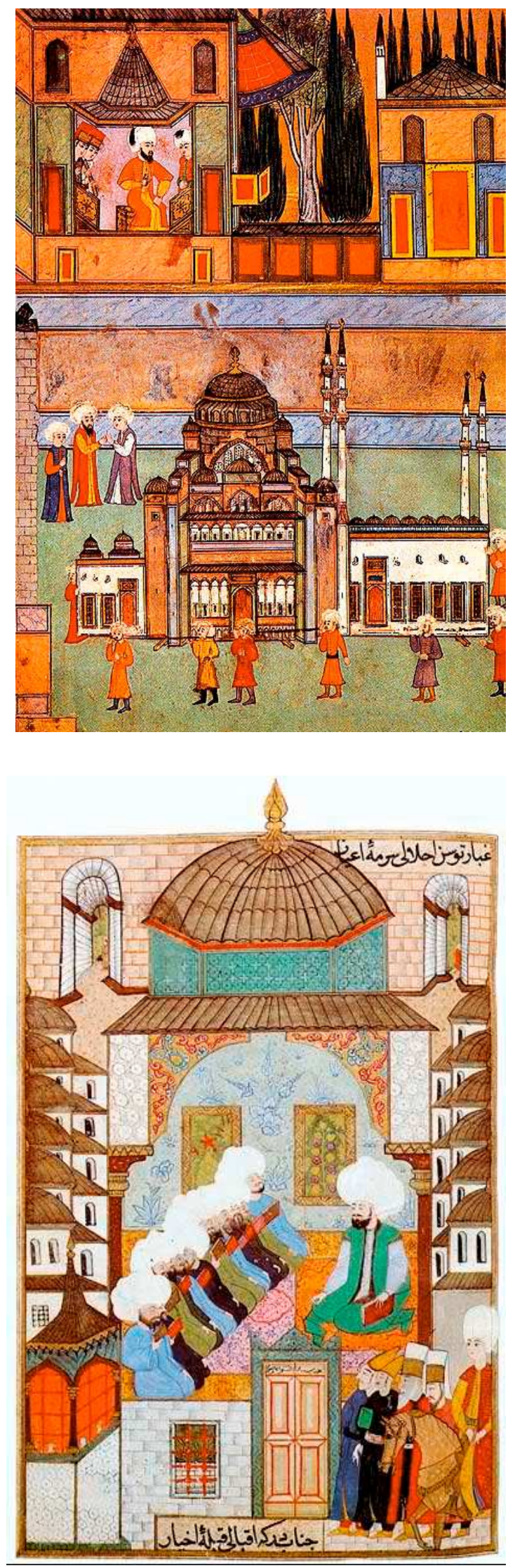

Figures 1 \& 2: Examples of Ottoman miniature paintings (images downloaded from http://sanat-

sanatkar.blogspot.com/2011/12/turk-susleme-sanatlarminyatur.html, retrieved 4 March 2012).

\section{PARALLELISM BETWEEN STREET PHOTOGRAPHY AND OTTOMAN MINIATURES}

Street photography has always been one of the most practiced and 'straight' photography forms. Photography, to many people, is a visual expression platform that conveys reality; even though this aspect was and is still being questioned after misleading or misused documentary photographs that were exploited to manipulate information. Street photography, being the most typical documentary photography practice, usually captures scenes from daily routines / idiosyncrasies of people. So does the Ottoman miniature; in addition to imperial depictions, the content of the visual expression may also "focus on the everyday life of the middle and lower classes, the activities of the trades and guilds, and the rites of religious fraternities. This style shows much greater spontaneity." (Ettinghausen, et al 1961)

In later periods, i.e. "in the seventeenth century, among the new subjects depicted in Turkish miniatures were representations of common people, by themselves or together with highranking people, shown in various aspects of their daily lives." (Bosworth, et al 1989) "After Levni [Ottoman Court painter (1680-1732), one of the last representatives of classical Ottoman miniature art], Westernization of Ottoman culture continued and, with the introduction of printing press and photography, no more illuminated picture manuscripts were produced. So the miniature painting lost its function." (Wikipedia 2012a) This very fact supports the assertion that Ottoman miniature painting was not purely intended as a subjective art form but more as a visual documentary apparatus.

There is a never-ending relationship between photography and painting. When photography was invented, it took painting's function of recording history and was more trusted as a documentary tool since it witnessed experiences more realistically than paintings, which are actually constructs from scratch. Miniatures of the Ottoman period followed the same course. "Portraiture in Turkish miniature art existed as a continuing tradition until photography took its place in the nineteenth century." (Bosworth, et al 1989) Despite the fact that both visual languages, i.e. miniature painting and photography, seem to be equivalent in their documentary approach; there is a major difference in the way the resulting pictorial representations are disseminated. Miniature paintings are created as unique plates that only a limited number of people can see, while photographs can be reproduced in a multiple number of prints that can reach a larger number of people. 




Figure 3: Example of an Ottoman miniature painting depicting street life (image downloaded from http://sanatsanatkar.blogspot.com/2011/12/turk-susleme-sanatlarminyatur.html, retrieved 4 March 2012).

\section{ABSTRACTION OF OBJECTIVE REALITY AND INTRODUCTION OF SUBJECTIVITY}

Although Ottoman miniatures can be considered as $2 \mathrm{D}$ representations, they carry the potential of conveying an individual's perception in a more detailed manner, compared to 3D perspective renderings. In a typical 2-vanishing-point perspective; objects / subjects drawn in the foreground hide the ones that are located at their back: This phenomenon is called occlusion. Occlusion has the disadvantage of being unable to transmit a thorough depiction of a locale that is to be visualized, since components of the illustration may veil others in the front-to-back cascading structure. In Ottoman miniatures there is no occlusion; the foreground is drawn at the bottom and the background is at the top. Components of the drawing do not cover, or even shade each other in the absence of directional light. All object / subject illustrations are holistic, there is no partial description of figures. Consequently, we end up with a life form that is the synthesis of individual forms, a sui generis state. This unique visual narrative can be extended to cubist works where multifaceted descriptions are observed. As an example; "Matrakci Nasuh was a famous miniature painter during the reigns of Yavuz Sultan Selim and
Süleyman the Magnificent. He created a new painting genre called topographic painting. He painted cities, ports and castles without any human figures and combined scenes observed from different viewpoints in one picture." (Wikipedia 2012a) Having multiple viewpoints and perspectives in one image is one of the key methods of Cubist art.



Figure 4: Example of a map-like Ottoman miniature painting depicting Istanbul's urban texture with no occlusion (image downloaded from http://imageshack.us/f/124/304stanbul11za2.jpg/, retrieved 4 March 2012).

Following the subjective cubistic approach described above, despite the fact that Ottoman miniatures were documentary in nature, one must be aware that this is a limited type of objectivity and realism. "One is tempted to say that Turkish miniature, remained suspended between East and West, idealism and realism, the Middle Ages and the Renaissance, fantasy and observation. It is perhaps in this dualism that its strength and its weakness should be seen: its strength, when it succeeds in reconciling the two different worlds and modes, its weakness when it hesitates and makes only irresolute steps in one or the other direction." (Ettinghausen et al 1961) A similar suspension also exists in photography. Though objectivity is much valued in photography, ideal objectivity is not possible since representative images are created by subjects and subjects belong to cultures that have different criteria in forming / perceiving 
portrayals. Moreover, tools that are used for visual representations usually prove to be narrower than the scope of human perception; as for instance, a camera has a limited capacity for rendition of light and yields photographs that have an exposure latitude more restricted than human eyes'.

Going back to the miniature paintings, "in the representation of the towns an arbitrary, fantastic perspective permits Matrakji (celebrated Ottoman historian and geographer) to present the most characteristic aspect of his subject without the encumbrance of any fixed rule. His book is saved by this expressionism from the monotony and cold objectivity of geographical maps. Some of them have the freshness of direct, personal observation." (Ettinghausen, et al 1961) Switching to the realm of photography back again, individuality in the visual language of a particular photographer stemming from 'personal observation' recurs here too. Martin Parr's street photography indeed has a unique contextual / visual approach as compared to Henri Cartier Bresson's; in terms of content, colors, processes, methods that are used. These two photographers are using the same tool to observe the street life in the straightest way possible, but still end up with different stories about what they have perceived to share. In this sense, they have abstracted the objective reality they conceived and introduced their own subjectivity in including what they wanted to tell and excluding what they found inessential.

Taking this comparatively minor level of subjectivity a little further to a higher level, it is possible to say that modern photography proved its independence and stopped being seen as evidence. This is when it found the opportunity to act like painting and be taken as an apparatus of fiction. "With the end of truth in photography has come a corresponding loss of trust; every image, every representation, is now a potential fraud. And as the eternal debate rages on about the appearance of truth and truth itself, simulation is the only truth we can trust. Through developments in digital technology, photography has been freed once and for all from the rigid conventions of Realism." (von Amelunxen et al. 1996)

\section{SUBJECTIVE HIERARCHICAL STRUCTURE IN THE LAYOUT OF MINIATURE PAINTINGS}

Miniatures make use of distance, void, shape, scale relationships and their layout to give a sense of depth in space. By accommodating an uncannily proper and appealingly modest organization, miniatures layer manifold perspectives in order to create the impression of a specific microcosm. Depth in the painting's layout is given in a very straightforward and consistent manner: More distant figures are designated by positioning higher up in the arrangement. This structure allows us to focus on certain aspects in the layout that reflect the painter's own perception, impressions, hierarchical priorities, sensibilities.

The ambient, global light that one finds in miniatures is like the one encountered in photographs taken under overcast skies: There is no obvious highlights-shadows / chiaroscuro configuration, all components in the scene receive the same quality and quantity of light, approximating the diffused light within photos taken in cloudy days.

One of the advantages Ottoman miniatures offer is that hierarchies of image and image maker are quite clear, like paintings drawn by children. More important figures are rather larger than those around them; biggest figure is at the top of the hierarchy and smallest at the bottom. "Very revealing, with regard to this theme of power, are the early portraits which show each person, whether sultan or high official, as a voluminous figure, so large indeed that he often nearly touches the edges of the painting." (Ettinghausen, et a/1961)

In addition to remaining "actual" by conforming to contemporary global approaches, artistic creation must also be nourished by local practices, traditions, habits in order to be as intrinsical as possible. The balance between a contemporary artistic expression and a practice concerned with local issues, culture, methods is of prime importance. The next section will focus on the artwork series of the author, and will attempt to show the relation of a present-day urban depiction to the deep-rooted convention of Ottoman miniature paintings.

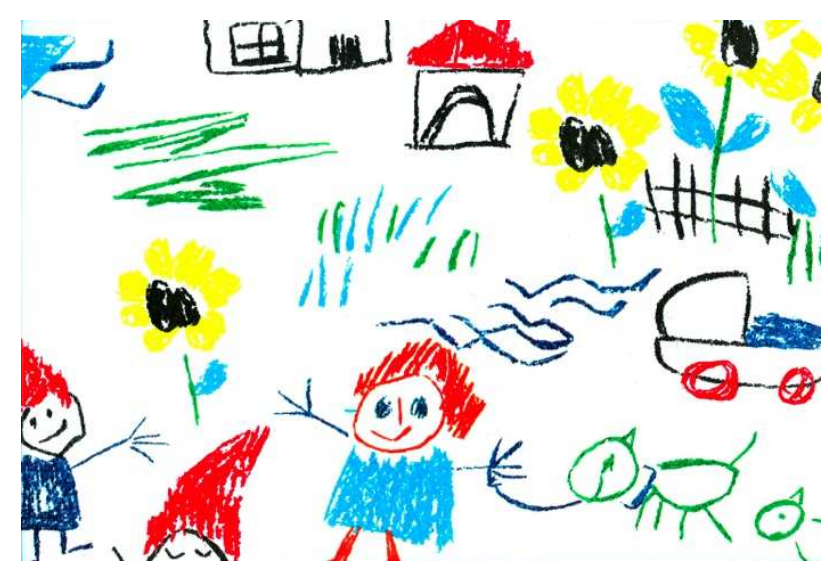

Figure 5: Example of a child drawing (image downloaded from

http://cauldronsandcupcakes.files.wordpress.com/2012/0 1/childs-drawing.jpg, retrieved 4 March 2012). 




Figure 6: Example of a child drawing (image downloaded from

http://migration.ucc.ie/children/images/drawing2.JPG, retrieved 4 March 2012).

\section{THE BIRTH OF THE SERIES CALLED MUTA- MORPHOSIS}

The unique aesthetics of urban compression that resulted after content-aware resizing, does not refer to the typical condensed image where each image component is affected by the single-direction scaling and gets excessively slender and tall. Rather, it is a textural fusion of intertwined image blocks that stayed relatively recognizable after the compression. The subsequent 'collage-city' pattern displays a structural connectedness to my previous architecture and city planning background. Concept text for the series of Muta-morphosis goes as follows: The different traces left by various people and slices of time coexist as layers in cities that have a particular past. The global trends and economical conditions strain this multi-layered traditional urban structure. An architecture with a language that cannot be considered as local anymore but universal, attacks the old texture of cities during the urban growth. This intervention usually implemented through gentrification supported by big capital, causes the urban tissue and its components to face mutation and even beyond this, undergo metamorphosis. Following this interaction and consecutive natural selection, some constituents disappear and some survive after being transformed.

The concept of 'muta-morphosis', a combination of the notions of mutation and metamorphosis, and the connected artwork series was obtained by reducing panoramic images on one axis. The image compression points to the dynamics between the urban components that can persist and the ones that give up, vanish in the various historical, residential and business urban districts. The visual urban result obtained after this contraction process points to the much discussed notion of evolution, where stronger components of existence survive the others after a natural selection process and change the course of life.

The formation of perspective in these works is different from that of photographs taken in a single shot and the scene depicted includes different time periods and spaces, though adjacent. The twovanishing-point perspectives of the single-pivotpoint panoramic imaging is diminished to an almost unnoticeable or flat perspective after the one-axis contraction in the horizontal array. Muta-morphosis series fits contents of multiple glances into one, visualizes what is there in a more condensed way. Photographs do not thoroughly convey what the naked eye sees, they include their author's interpretation, emphasize priorities in his perception. In other words, photos expect to be read like a novel and not like an objective / scientific / factual body of text.

Though photographs in this series are taken in various cities, metropolises in the world; majority of them depict Istanbul, as the Ottoman miniatures do. The author neither tries to beautify Istanbul more than necessary as old generation photographers did, nor picture Istanbul's spot ugliness excessively like new generation photographers prefer. In some works, both sides of Istanbul, divided by the Bosporus strait, can be observed. One side of the photo can include the Asian side where I attain peace and the right comprises the European where I find vibe, energy. The unusual coming together of the two sides reminds of the notion of equilibrium: East-West, calm-hyperactive, traditional-global...

\section{CONCLUSION}

Departing from the point of view outlined above, Mutamorphosis is a photography project that is created as a surreal visualization stemming from the real. The artwork series was obtained by reducing documentary panoramic images. The visual expression is a synopsis of piecemeal words that remained in mind during visits to various cities, and especially Istanbul. It is like a video footage that includes jerky movements of a stop-motion study with no smooth continuity. The lack of a single perspectival structure due to multiplicity of perspectives after panoramic imaging followed by compression, can be linked to Ottoman miniatures, which in turn, connects the global contemporary representation to its local traditional counterpart

Putting visual narration tools such as the Ottoman miniature paintings and the Muta-morphosis series aside, I conclude by addressing objectivity versus subjectivity. The concept of objectivity may be seen 



Figures 7,8,9,10: From top to bottom: Muta-morphosis \#98-99, diptych, Murat Germen, 2011, Istanbul / Muta-morphosis \#113, diptych, Murat Germen, 2011, Istanbul / Muta-morphosis \#115, diptych, Murat Germen, 2011, Istanbul / Mutamorphosis \#116, diptych, Murat Germen, 2011, Istanbul

as an institutional (or even religious) declaration that there is this 'one and the only' source of knowledge that can tell you what is true or not. This is why official texts of history belonging to different nations are taken as the sole truth on what occurred in the past. Countries, governments, kingdoms, states, administrations usually record the good deeds they have carried out into their written histories and not the misdeeds, mistakes, oppressions, inequalities they have realized. Nowadays, the current world history is no longer written only by various states or institutions. Individuals' statements and status updates declared through social media tools like Facebook 
and Twitter also constitute part of world history. Some people (including the author) prefer to follow tweets on world matters instead getting passively "informed" by the biased hegemonic news agencies that service filtered content to the entire world. Collective subjectivities is the new objectivity...

\section{REFERENCES}

Atasoy N. (1976) The Documentary Value of Turkish Miniatures. Quatrième Congrès International d'Art Turc, Aix-en-Provence, 10-15 September 1971, pp. 11-17.

Bosworth C. E., Issawi C., Savory R., and Udovitch A. L., eds. (1989) The Islamic World: From Classical to Modern Times. Princeton, NJ: Darwin Press, p. 393.

Ettinghausen R., Ipsiroglu M. S., and Eyuboglu S.
(1961) Turkey: Ancient Miniatures. Greenwich, CT: New York Graphic Society, pp. 6, 9, 10, 13, 18.

Rührdanz K. (1994) The Role of the Urban Ateliers in Ottoman Miniature Painting Since the End of the Sixteenth Century. CIÉPO IX Symposium, Jerusalem, 1994, p. 75. A. Singer and A. Cohen, eds., Hebrew University, Jerusalem.

von Amelunxen H. et al., eds. (1996), Photography after Photography. Exhibition catalog, Verlag der Kunst and Siemens Kulturprogramm, Munich, pp. 126-129.

Wikipedia. (2012a)

http://en.wikipedia.org/wiki/Ottoman miniature (retrieved 4 March 2012).

Wikipedia (2012b)

http://en.wikipedia.org/wiki/Miniature (illuminated manuscript) (retrieved 4 March 2012). 